Article

\title{
Landscape Optimization in a Highly Urbanized Tourism Destination: An Integrated Approach in Nanjing, China
}

\author{
Lingling Chen ${ }^{1, *}$, Brijesh Thapa ${ }^{2}$ (D), Jinwon Kim ${ }^{2}$ and Lin $\mathrm{Yi}^{3}$ \\ 1 Department of Tourism Management, College of Humanities, Jinling Institute of Technology, \\ Nanjing 210038, China \\ 2 Department of Tourism, Recreation \& Sport Management, University of Florida, \\ Gainesville, FL 32611-8208, USA; bthapa@hhp.ufl.edu (B.T.); jinwonkim@ufl.edu (J.K.) \\ 3 Shenzhen Institutes of Advanced Technology, Chinese Academy of Sciences, Shenzhen 518055, China; \\ lin.yi@siat.ac.cn \\ * Correspondence: chenlingling@jit.edu.cn; Tel.: +86-189-138-06873
}

Received: 27 October 2017; Accepted: 15 December 2017; Published: 19 December 2017

\begin{abstract}
Planning and developing urban tourism destinations must encompass landscape optimization to achieve healthy urban ecosystems, as well as for evolution sustainability. This study explored sustainable landscape planning by examining the optimization of landscape spatial distribution in an urban tourism destination-Nanjing, China-using an integrated approach that included remote sensing (RS), geographic information system (GIS), and landscape metrics in the context of an urban tourism destination evolution model. Least-cost modeling in GIS was also used to optimize decision-making from an ecological perspective. The results indicated that landscapes were more homogenous, fragmented, and less connected. Except for the eastern area, the landscape evolution showed characteristics of both degeneration and growth. A complete greenway network including sources, greenways, and nodes were constructed, and an increase in natural landscapes was strongly recommended. The findings provide geographic insights for sustainable urban tourism planning and development via comprehensive methodological applications.
\end{abstract}

Keywords: tourism destination planning; landscape evolution; urbanization; integrated approach; greenways

\section{Introduction}

Urban environments that include libraries, museums, amusement parks, and unique, natural, or heritage sites are used as tourist attractions, and have become increasingly popular among visitors in recent years [1,2]. Because of growing development, urban destinations are confronted with myriad challenges associated with increased residential population, economic activities, and visitor influx. Moreover, the demand and competition for limited real estate has resulted in major transformation of land use for development of both urbanization and tourism, which has had major effects on the landscape and ecology [3-5].

From an ecological perspective, the services that landscapes provide to humans include biological diversity, recycling nutrients, carbon sequestration, clean water, etc. [6]. Understanding the landscape changes attributable to urbanization and tourism is critical for destination planning, management of land resources, and provision of services in rapidly changing environments. While the significance of landscape structure and pattern change in urban areas has been examined [7-9], the dynamics in response to urban tourism are poorly understood [10]. In addition, the relation to other aspects of planning urban tourism destinations has not been comprehensively assessed. In the context of 
urban tourism research and management, issues have largely focused on destination life cycle and its application to development [11], competitiveness [12], and community-based tourism planning [13]. However, the role of landscape evolution in urban ecology and tourism has not been adequately addressed in planning and developing urban tourism destinations. Consequently, such planning and development must encompass landscape optimization to achieve ecological and evolutional sustainability that are necessary for healthy urban ecosystem and sustainable tourism development.

In this context, the ability of geographical information system (GIS) to address multiple spatial criteria makes it an important tool in the allocation of resources, and can assist decision-makers in planning for sustainable tourism [14]. However, its application has been relatively limited in tourism development [15]. Further, Remote Sensing (RS), which is invaluable in monitoring shortand long-term landscape changes and the effect of human activities [16], can also be integrated with GIS to plan tourism from a landscape perspective. Also, it can be used to evaluate the characteristics and ecological consequences of spatiotemporal changes on various scales $[16,17]$. Because of their widespread availability, frequency of coverage and improved quality, RS and GIS have become valuable tools that are used extensively to monitor landscape changes and urbanization [5,7]. Additionally, the ability of a variety of landscape metrics in the statistical package FRAGSTATS to indicate the spatiotemporal landscape pattern and the ecological process from thematic maps has been used and discussed $[5,18]$. Specifically, according to several urban planners and geographers, landscape metrics can be used as geospatial metrics because they assist to quantitatively assess the urban spatial structures and patterns [19]. In general, landscape spatial analysis that includes classification, pattern and function analysis, and evaluation and planning can be achieved with comprehensive application of RS, GIS and landscape metrics. Recently, these three technologies have been widely used in the studies with respect to ecological impact of urban expansion $[5,9,16]$.

In view of this, the purpose of this study was to explore sustainable landscape planning by examining optimization of landscape spatial distribution in a highly urbanized tourism destination-Nanjing, China. The drastic urbanization and large-scale tourism have become two of the most fundamental characteristics of Chinese economic and social development in this century $[9,11]$. Consequently, there has been significant growth in highly urbanized destinations, as well as rapid development in urbanization and tourism. Nanjing was chosen for this study because of its mature tourism industry and major urbanization initiatives. An integrated approach was used that includes RS, GIS and landscape metrics to collect, process, and analyze data in the context of an urban tourism destination evolution model. In addition, the least-cost modeling in GIS was utilized to aid in optimization decision-making from an ecological perspective. Overall, the comprehensive application of these methods can play a key role in understanding planning and development based on an assessment of an urban tourism destination through landscape change over time.

\section{Literature Review}

\subsection{Tourism Planning and GIS Application}

With rapid expansion of tourism, major attention has been levied towards effective planning with respect to community participation, resource development and management [10,20-22]. Freestone [23] summarized the evolution of urban planning in the 20th century, and noted the traditional town planning would transfer into green town planning, and the town itself can be planned as a big tourist attraction. Contemporary approaches have widely recognized that the long-term success of any tourism destination is achieved when local community perspectives are considered in the planning process $[24,25]$, and this relationship has become a key focus in tourism planning $[13,26]$. On the other hand, policies and planning for tourism destinations have largely been grounded theoretically on evolutionary models from the 1970s and 80s, which provides an important focus for tourism destination management [27-29]. 
GIS can be used to capture data, conduct scientific-based analysis, define objectives, scenarios and alternative futures and planning measures, etc., which offers capabilities to assist in planning and management [30]. Since tourism planning requires additional spatial data collection and processing, the role of GIS has been regarded as one of the most important scientific tools to assist in sustainable tourism initiatives, government strategy, and decision making [31,32]. GIS can integrate different types of relevant data, such as landscape elements, tourist locations and temporal-spatial behavior. Subsequently, a decision-support model can be added to analyze the overall spatial behavior and draw the best conclusions [33-37]. Moreover, GIS has been applied to measure the level of accessibility and distribution equity offered by public parks systems [38,39], assistance in conceptual tourism infrastructure planning framework inclusive of attractions, services and transportation facilities [32], measurement of landscape aesthetic and visual qualities [40], assessment of categories of ecological sensitivity in sensitive areas [14], national park planning, and ecotourism site planning, among others [41-43]. In general, while GIS applications in tourism planning and management have increased gradually since the early 1990s, it has yet to be widely used in comparison to other disciplines [15], and even less in the planning of a tourism destination, especially in China [44].

\subsection{Landcape-Based Urban Tourism Destination Planning}

While short- and long-term urban planning cannot be achieved without considering the ecology [45], urban areas tend to be viewed as social and engineering inventions in which ecological processes may legitimately be neglected [46]. Cadenasso and Pickett [47] noted that ecological processes should not be excluded, especially in urban natural landscape that includes parks, rivers, lakes, wetlands, forests, ponds, etc., which are all vital as they serve ecosystem functions and provide services [48,49]. Chen et al. [50] proposed a source-sink landscape theory and illustrated that source landscapes contribute positively to the ecological process, while sink landscapes may impede the healthy ecological process, between which various ecological corridors play a role in transmission. The arrangement of these landscape elements, which constitutes an ecological network that guarantees connectivity and continuity, determines the resistance to flow or movement over a landscape on the part of species, energy, and material [51,52].

In urban areas, greenway system, as a type of ecological network, has been widely established and practiced due to its ecological, social, economic, aesthetic, and recreational function, etc. [53,54]. Developing greenways is an effective approach for eco-regional planning in human-modified landscapes, in which rapid urban sprawl, tourism growth and other human activities frequently sever urban connectivity $[55,56]$. There has been increasing interest in characterizing and quantifying the temporal dynamics of the landscape spatial patterns affected by urbanization $[4,5,9]$. However, to date, less attention has been noted to the value of landscape connectivity for the ecosystem services and functions during urban or tourism destination planning [1,46], which can be achieved by greenways, ecological network, blue-green networks, riverways, among others [51].

From a tourism perspective, as landscapes are fundamental assets, it is imperative to explore their value in relation to planning, maintenance, restoration, and development [30,57]. Urban region is the area of active interactions between a city and its surroundings, mainly dominated by human activities and basically covered by two components, i.e., built spaces and open spaces [58]. When more landscapes of these two components are protected or constructed for tourism, this phenomenon may be viewed as urban tourismization. Hence, Yu and Wang [59] assumed that landscape transformation and evolution could reflect the development choice with pure urbanization. Although the effect of landscape on urban expansion and landscape architecture has been noted $[7,60]$, the importance of landscape evolution within urban tourism destination evolution and planning has received limited attention.

Additionally, Zhang et al. [61] highlighted the main objective of physical planning is to optimize the distribution of landscapes and focus on land-use allocation to achieve regional sustainability. Although landscape optimization is an ongoing discipline and simulation models are recognized as efficient tools, the modeling techniques still differ considerably from one problem to another $[62,63]$. 
Therefore, in the context of interactions among urban tourism and urban ecosystem, landscape planning and optimization is of significant importance for in-depth development of theory and practice in urban tourism destination.

\section{Study Area}

As the capital of Jiangsu Province and a central municipality of Eastern China, Nanjing is one of the four ancient capitals that has national historical and cultural importance. The city boasts nearly 2000 years of history, and is viewed as one of the most important birthplace of Chinese civilization. Nanjing has experienced rapid urbanization, increasing from $48.6 \%$ in 1978 to $81.0 \%$ in 2015 , a growth rate $24.9 \%$ higher than the national average [64]. The focus of this study was the core area in Nanjing, which consists of five sub-areas that extend from east of the surrounding highway to south of the Qinhuai River, and west and north of the Yangtze River. The total area is approximately $375 \mathrm{~km}^{2}$ (Figure 1). Moreover, the basic topographic information is provided by the map with a gradual descent. The western part is relatively flat, while the eastern, southern, and northern part as mountainous and hilly (Figure 2).

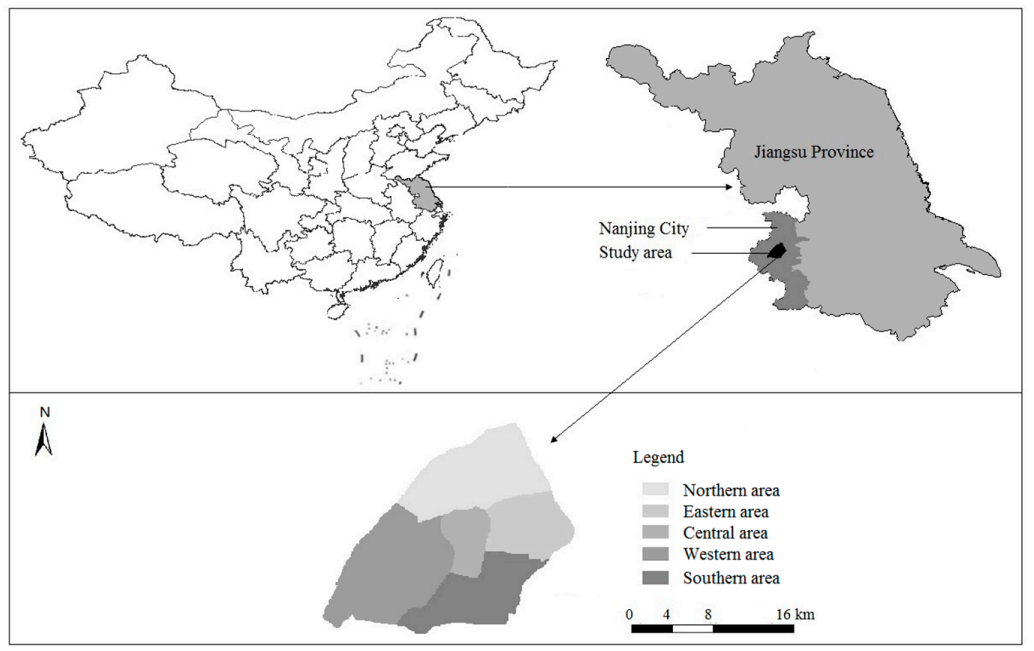

Figure 1. Study area-Nanjing and its five sub-areas.

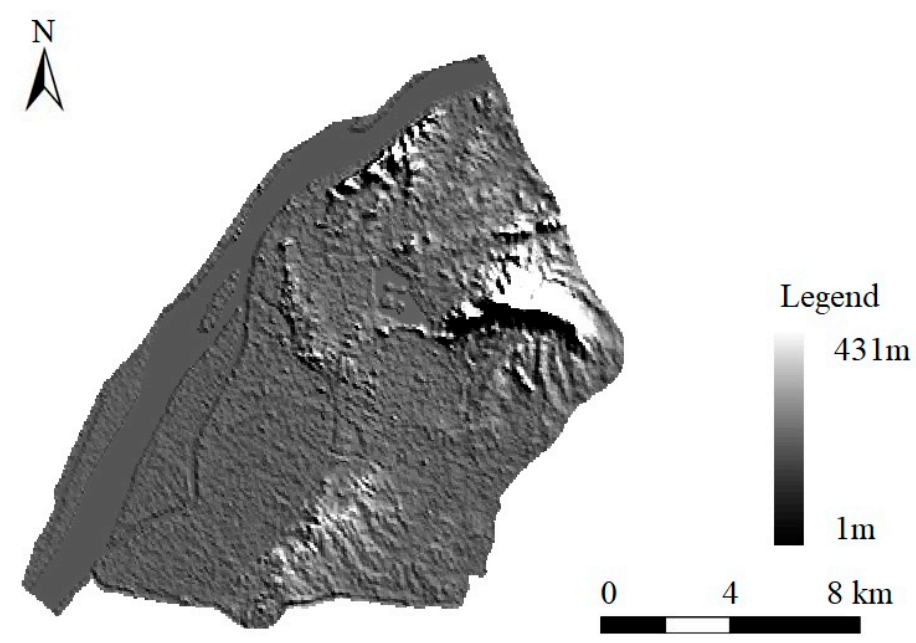

Figure 2. Topographic map of study area.

This study area has two main characteristics: (1) it is a key development area in Nanjing and has undergone tremendous changes due to urbanization. Frequent human activities and drastic 
land use and land cover changes have led to significant transformation of the urban landscape; and (2) key tourist resources are distributed widely throughout the area. These include the Ming Xiaoling Mausoleum (World Cultural Heritage Site); Zhongshan Scenic Area, and Confucius Temple-Qinhuai Scenic Belt, which have both natural and cultural landscapes and are two of the highest-rated scenic locations in China. The area also has other famous natural and cultural landscapes. Most tourism activities occur in this area and thus, Nanjing is viewed as a noted urban tourism destination.

The main factors that influence the urban sub-area include landscape spatial heterogeneity, land use/cover characteristics, and economic development and administrative division. For data collection, five sub-areas were created from the larger research area to formulate an in-depth assessment of landscape change at different scales. This case study overall can serve as a representative examination of destination sustainability under influence of urbanization and tourism.

\section{Materials and Methods}

\subsection{Data Collection and Processing}

Multispectral RS imagery was collected to obtain land use data, including Landsat TM imagery from 1991 (spatial resolution of $30 \mathrm{~m} \times 30 \mathrm{~m}$ ), Landsat ETM+ imagery from 2003 (spatial resolution of $15 \mathrm{~m} \times 15 \mathrm{~m}$ ), and High Score One imagery from 2014 (spatial resolution of $8 \mathrm{~m} \times 8 \mathrm{~m}$ ). All images were clear and nearly free of clouds.

Image registration of the RS images was performed via Erdas software. Combined with the administrative and topographic map, the images were cropped to obtain images of the study area. Interpretation marks were established according to the image features of different land use types combined with a field survey. Further, ArcGIS was conducted for visual interpretation, and ten land use categories characterized by a high degree of urbanization were used. The classifications included open spaces which include forest, tidal, water bodies (i.e., rivers, lakes, channels, ponds, and reservoirs), park and green land, arable, and bare land, and built spaces (i.e., built-up, transportation, industrial storage, military land) (Figure 3). According to field validation and accuracy testing, the accuracy of classification over the study period was determined to range from $84.01 \%$ to $93.13 \%$, with an average of $87.84 \%$, and the Kappa coefficient ranged from 0.77 to 0.82 , with an average of 0.79 [65].

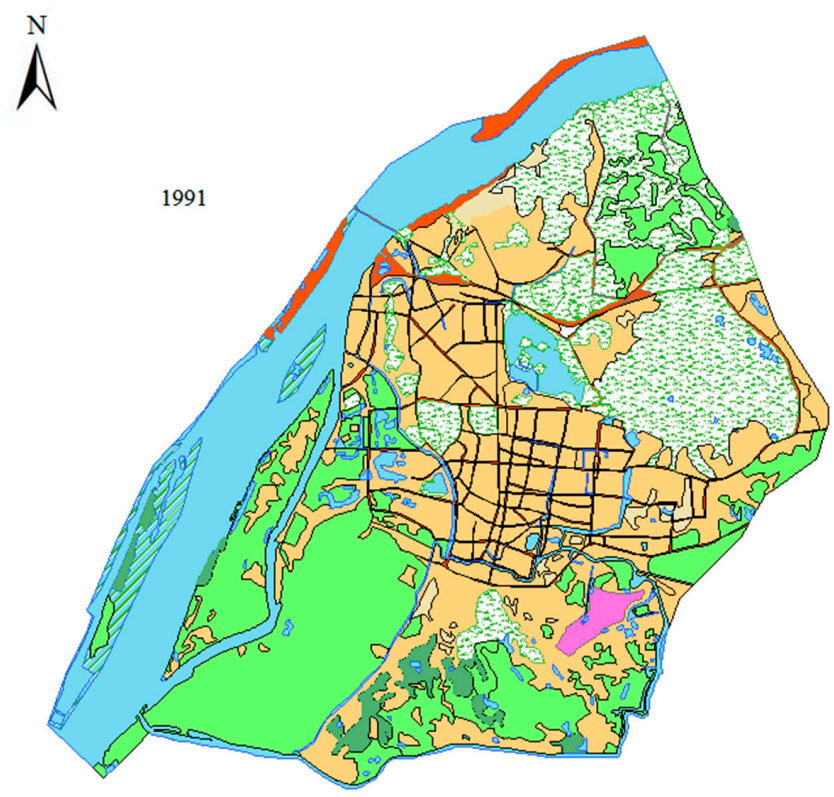

(a)

Figure 3. Cont. 


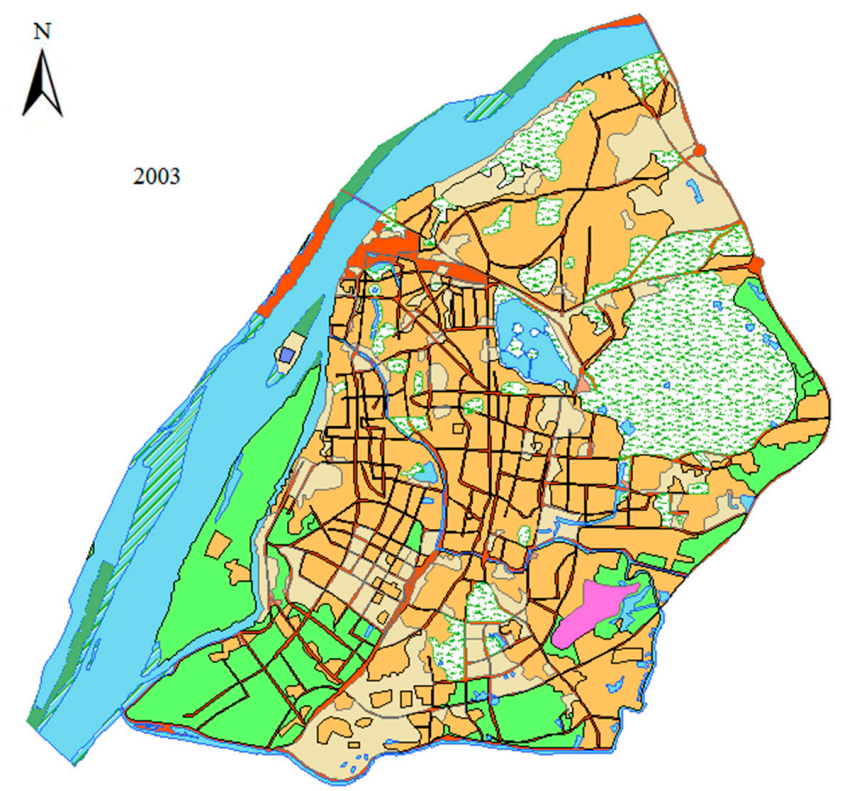

(b)

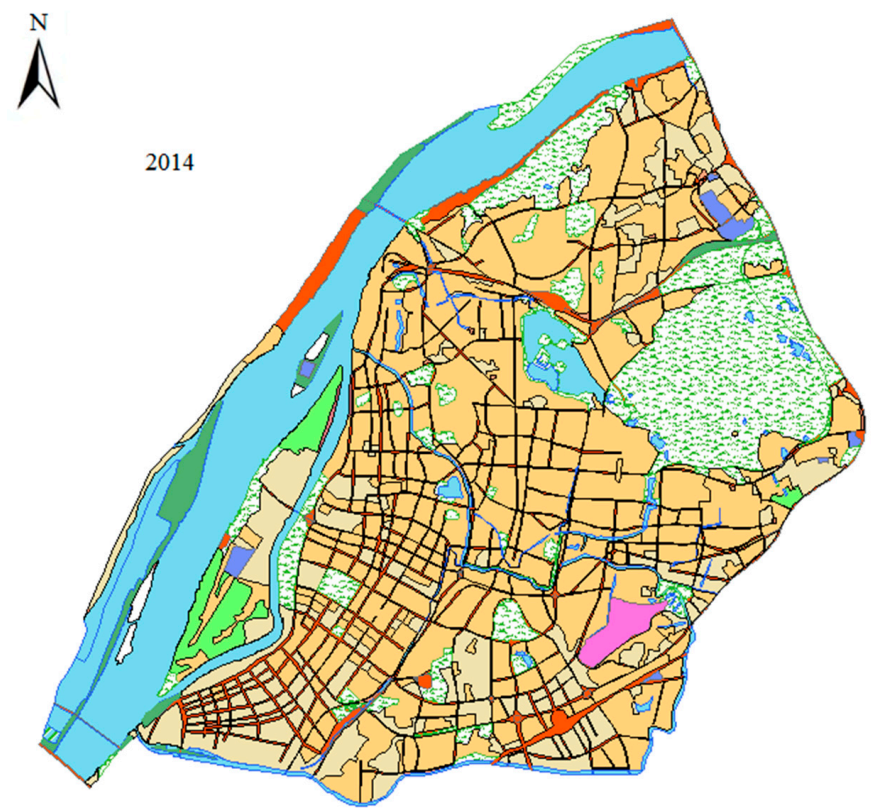

(c)

Legend

$$
\begin{aligned}
& \text { Forest } \\
& \text { Tidal land } \\
& \text { Water } \\
& \square \text { Park \& Green } \\
& \square \text { Arable land } \\
& \text { Bare land }
\end{aligned}
$$

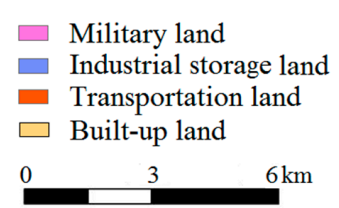

Figure 3. Land use map of the study area in (a) 1991; (b) 2003; and (c) 2014.

From a tourism perspective, further classification of landscapes was conducted based on whether the external or internal value was related to tourism in the area. Accordingly, park and green land, tidal land, forest, and water bodies were defined as natural tourism landscapes because of their natural and ecological characteristics. In contrast, military, industrial storage, arable, and bare land were classified as non-tourism landscapes with no tourism-related value. 
Built-up and transportation land included both human induced tourism and non-tourism landscapes. Built-up land included architectural heritage sites, relics, and places with athletic, recreational, ornamental, or other special value as human induced tourism landscapes. Others that were irrelevant for tourism constituted the non-tourism landscape. Similarly, road landscapes formed by transportation land with local characteristics were regarded as human induced tourism landscapes, while the ordinary transportation land were considered to have no tourism value.

\subsection{Landscape Metrics}

To calculate the landscape metrics, following visual interpretation, FRAGSTATS 4.2 was used to transfer the images for the three periods into Arc Grid format based on all quantitative measures. Landscape metrics was selected based on follows: (1) comparability with previous studies of landscape ecology [8,16,66]; (2) association with sustainability [5]; (3) low redundancy among the metrics [67]), and (4) reflection of the landscape pattern characteristics for the study area. Based on these, an index of the percentage of landscape (PLAND) at the patch level was selected to illustrate the landscape composition, while the number of total patches (NP), landscape fragmentation index (F), Shannon's diversity index (SHDI), dominance index (D), and connectivity index (C) at the landscape level represented the configuration.

\subsection{Least-Cost Modeling}

From the perspective of landscape ecology, a large area of natural land with high ecosystem services value (i.e., forest land, grassland, lake, wetland, etc.) can promote the healthy ecological process, namely source, however, sink landscape plays an opposite effect, such as built-up land $[49,50]$. In order to enhance the connectivity between source and sink, ecological corridors are usually constructed to connect the relatively isolated and dispersed landscape units [48], which have three main types, i.e., linear, strip, and stream $[68,69]$. In urban areas, linear greenways are corridors of various widths, linked together in a network [70], which could serve for the movement of wildlife and humans [71], protect and create green spaces [55], as well as play a role in the promotion of urban tourism due to their leisure, recreational, aesthetic function, etc. [72]. Moreover, the construction of greenways can assist to enhance the ecological function of urban corridors [73], such as greenways established along the riverfront, or overland along a canal, road, etc. In view of this, a greenway network was constructed based on least-cost modeling to assist the destination to achieve ecological sustainability.

On the landscape scale, the movement of landscape flow must overcome a certain resistance from source to sink. Based on the friction maps in raster format (generically as cost surfaces in the GIS literatures) [74], least-cost modeling is applied to acquire the least costly path from each cell location to a source [75]. First, via the calculation of the sum of the expansion resistance coefficient values of all pixels between each cell with the source, least-cost modeling calculates the accumulated cost distance from each path to generate the accumulated cost surface. Afterwards the shortest cost distance between each cell with the nearest source is determined [76,77].

In GIS, the least cost-distance analysis can be achieved with the COST DISTANCE module in the spatial analysis tool, which models the functional connectivity among landscapes, and shows elements with weak connectivity that could be restored. Recently, least-cost modeling has received growing attention in applied land- and species-management projects, as well as in greenway planning, not least because toolboxes have become available in most current GIS packages [73,77-81].

\subsection{Conceptual Landscape Evolution Model}

According to characteristics of Chinese urbanization, Yu and Wang [59] proposed a conceptual evolution model of urban tourism destinations that used landscape metrics PLAND as the main index to define the evolution process. The change in PLAND of landscape types could be attributed 
to various driving forces that result from the interests of stakeholders, including the government, enterprises, tourists, and residents, among others.

This study configured the two evolution stages based on Yu and Wang's [59] model (Figure 4). Basically, if the PLAND of tourism landscapes increases while that of non-tourism landscapes decreases (i.e., the tourism value of the landscape increases), then the destination is in the tourism-oriented evolution stage. Conversely, if the PLAND of tourism landscapes decreases while that of non-tourism landscapes increases, then the material production function of the landscape, but not the tourism function increases. In this case, the destination can be described to be in a non-tourism-oriented evolution stage. Accordingly, urban tourism destinations can be categorized as growing, degenerated, and stable destinations [82].

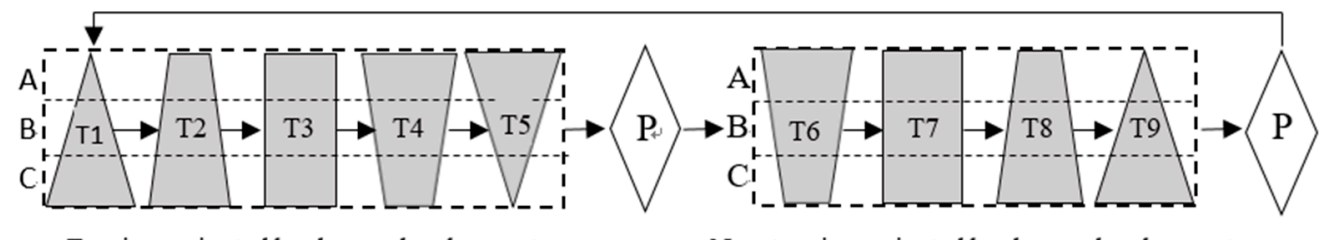

Tourism-oriented landscape development Non-tourism-oriented landscape development
A:-PLAND'of tourism landscape; B:PLAND of 'transitional tourism landscape;
C:PLAND-of-non-tourism landscape;P:Planning orientation choice

Figure 4. Conceptual evolution of urban tourism destination based on landscape (modified from Yu and Wang [59]).

\subsection{Research Framework and Data Analysis Procedure}

To further examine the aforementioned issue of landscape optimization in an urban tourism destination, a research framework was formulated based on an integrated approach. This approach allows identification of historical landscape changes, evolution, and optimization from the perspectives of urban ecology and tourism destination evolution (Figure 5).

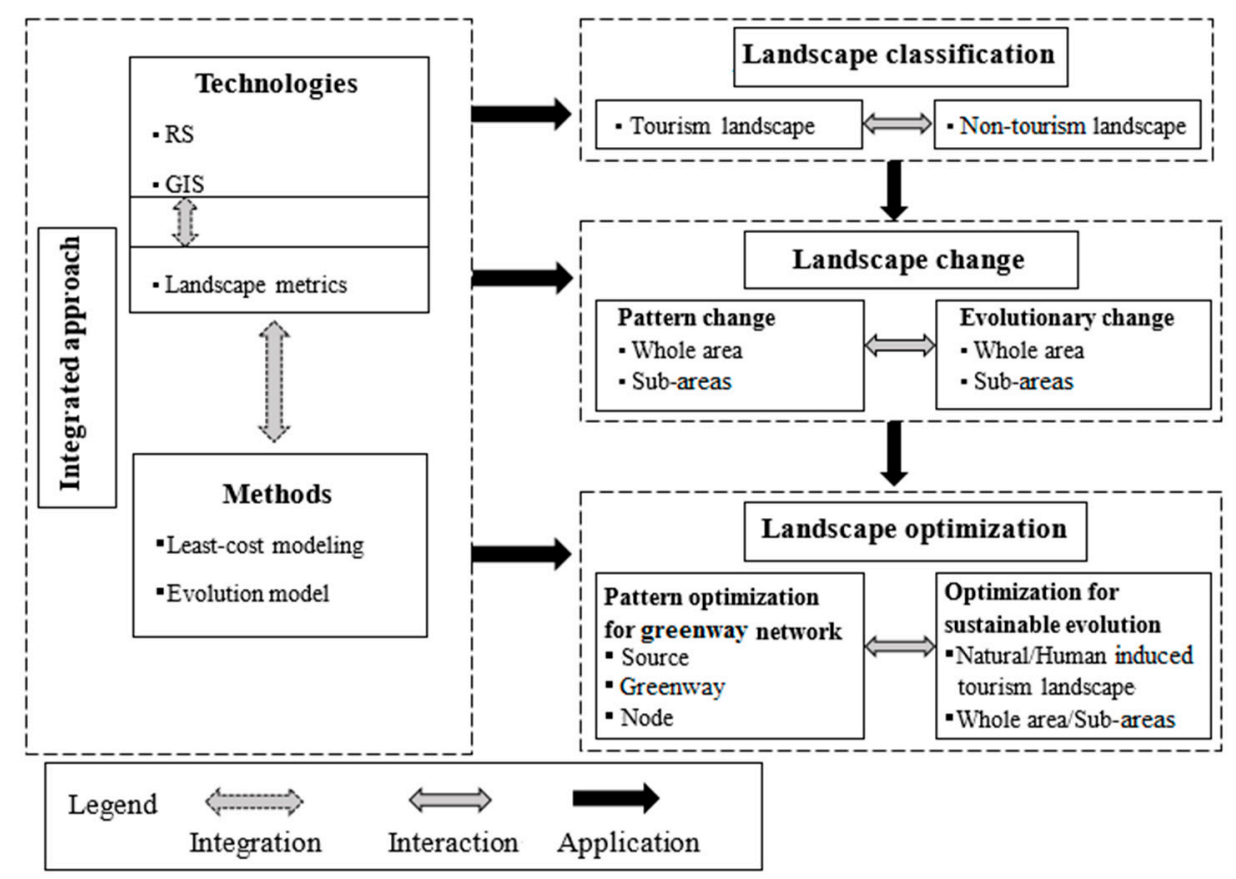

Figure 5. Framework of landscape optimization in an urban tourism destination. 
Based on the research framework, a detailed methodological stepwise process was developed to illustrate the data analysis procedures (Figure 6).

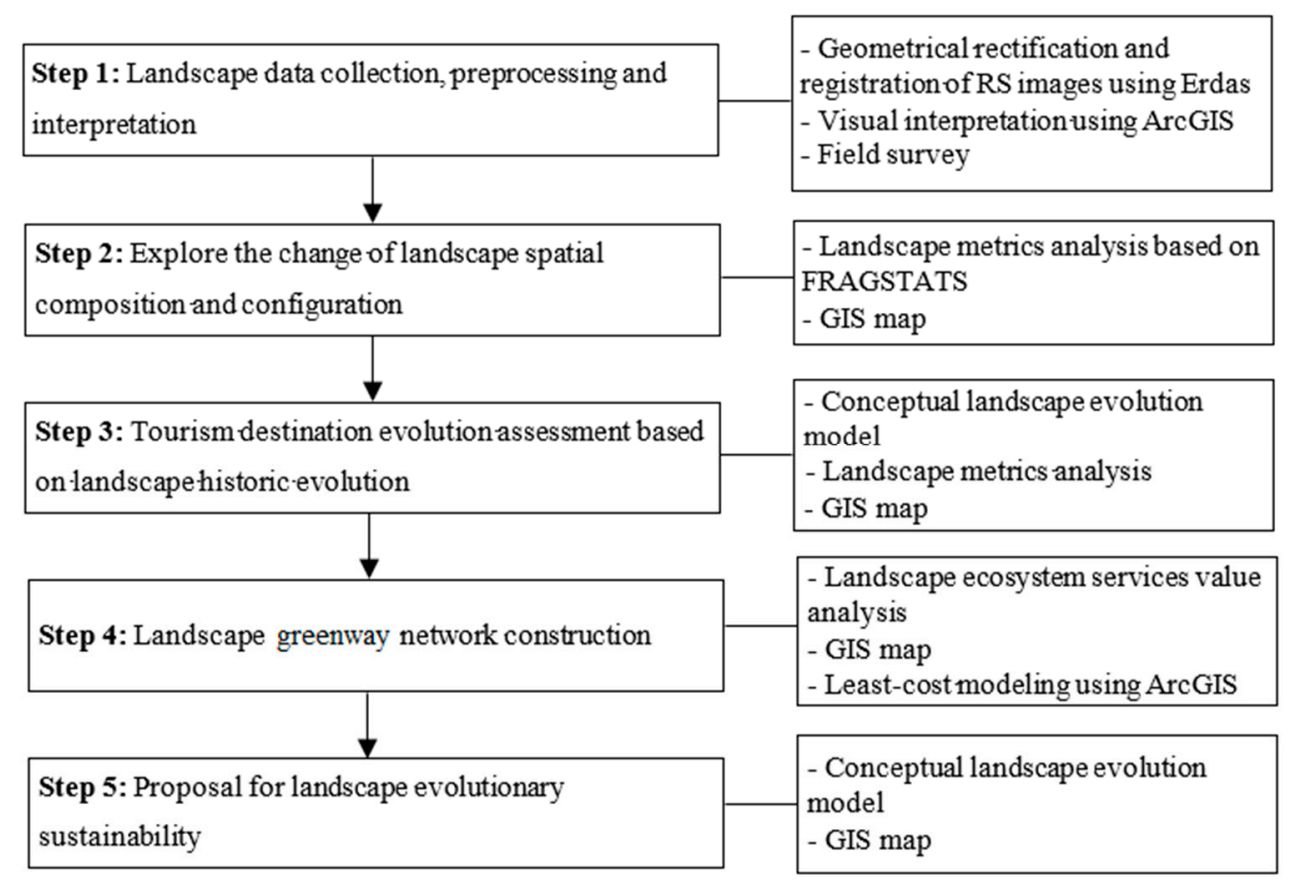

Figure 6. Data analysis procedure.

\section{Results}

\subsection{Landscape Change and Evolution}

\subsubsection{Landscape Configuration Change}

From the metrics analysis, the number of patches (NP) increased from 861 to 1595, which is indicative of urban land subdivisions. The fragmentation index (F) increased from 0.23 to 0.42 and showed continued landscape fragmentation attributable to human disturbance. Shannon's diversity index (SHDI) rose from 1.70 to 1.87 initially, and then decreased significantly to 1.66 due to increased urban construction landscapes that included built-up and transportation types. The trend of dominance index (D) declined from 0.29 to 0.22 first and then increased to 0.33, which indicated that the construction landscape became dominant during the second research period (2003-2014). In addition, the connectivity index $(C)$, measured as the degree to which the landscape promotes or impedes the resource patches' movement, decreased from 85.86 to 60.95 which demonstrated detrimental effects on the landscape's ecological processes (Table 1).

Table 1. Landscape metric changes in the study area.

\begin{tabular}{cccccc}
\hline Year & NP & F & SHDI & D & C \\
\hline 1991 & 861 & 0.23 & 1.70 & 0.29 & 85.86 \\
2003 & 1173 & 0.31 & 1.87 & 0.22 & 63.50 \\
2014 & 1595 & 0.42 & 1.66 & 0.33 & 60.95 \\
\hline
\end{tabular}

\subsubsection{Landscape Composition Change}

PLAND provides a general understanding of landscape composition, specifically the degree to which the landscape represents a particular patch type. The PLAND change in water landscapes were 
similar to the park and green land, which experienced a process of decline in the first stage (1991-2003), and then increased thereafter (2003-2014). The PLAND of tidal land rose slightly before 2003, and then declined rapidly, while forest exhibited a steady state before 2003 followed by an increasing trend. The PLAND of transportation land increased rapidly from 3.90\% to $8.05 \%$ from 1991 to 2003, and then remained nearly unchanged, which reflects that the construction of the road network approached saturation recently. The PLAND of built-up landscape increased slowly during the first stage and rapidly in the next, and has become the dominant landscape type with improvement by more than $35 \%$ during the research period. The significant increase in transportation and built-up land depends highly on urbanization, and reflects its major achievements (Table 2).

Among the non-tourism landscape types, the total PLAND of military, and industrial storage land remained within 1.5\% (from 1991 to 2014) with a minor decrease. Arable land decreased continually and had nearly vanished before 2014. In the study area, bare land mainly composed of the leveled land awaiting future development. Also, there was large-scale urban demolition and transformation from 1991 to 2003, which resulted in a large amount of bare land, and the PLAND of which maintained approximately $10 \%$ from 2003 onwards (Table 2).

Table 2. PLAND change of different landscape types (unit: \%).

\begin{tabular}{ccccc}
\hline Type & & $\mathbf{1 9 9 1}$ & $\mathbf{2 0 0 3}$ & $\mathbf{2 0 1 4}$ \\
\hline & Water & 21.29 & 17.96 & 20.54 \\
& Park and Green & 17.19 & 13.35 & 15.29 \\
Natural tourism landscapes & Tidal land & 2.07 & 2.25 & 0.05 \\
& Forest & 1.87 & 1.41 & 2.86 \\
& Total & 42.42 & 34.97 & 38.74 \\
\hline \multirow{2}{*}{ Human-induced tourism landscapes } & Build-up land & 29.46 & 30.83 & 39.79 \\
and non-tourism landscapes & Transportation land & 3.90 & 8.05 & 8.15 \\
& Total & 33.36 & 38.88 & 47.94 \\
\hline \multirow{2}{*}{ Non-tourism landscapes } & Arable land & 22.29 & 13.06 & 1.69 \\
& Bare land & 1.25 & 12.37 & 10.41 \\
& Military land & 0.66 & 0.69 & 0.66 \\
& Industrial storage land & 0.02 & 0.03 & 0.56 \\
& Total & 24.22 & 26.15 & 13.32 \\
\hline
\end{tabular}

\subsubsection{Landscape Evolution}

To determine the evolution characteristics from the relationship between tourism and non-tourism landscapes, the total PLAND of the four natural tourism landscapes decreased in the first stage. The PLAND increased in built-up and transportation landscapes because of the large-scale of ordinary transportation construction (3.90-8.05\%), and a minor increase in built-up landscape. According to the field survey of the time open and area, 36 human induced tourism landscapes, most of which were tourism hotels completed during 1991-2003 (Figure 7), and their total PLAND was less than 1\%. Consequently, the total PLAND of tourism landscapes (i.e., natural and human induced tourism landscapes) still decreased while the non-tourism landscapes increased during the first stage. In the second stage, more natural landscapes and another 34 human induced tourism landscapes increased (Figure 7), while large-scale non-tourism landscapes transformed into tourism landscapes. Basically, this led the opposite to occur by comparison to the first stage. In the context of the conceptual evolution model, the first stage could be defined as a non-tourism-oriented landscape evolution stage, and the second as tourism-oriented stage.

With respect to the sub-areas, from a quantitative perspective, most of the human induced tourism landscapes completed were concentrated in the central area, accounting for $65.51 \%, 63.07 \%$, and $55.56 \%$ of the total area in 1991, 2003, and 2014, respectively (Figure 7). According to the field survey, 22 human induced tourism landscapes were constructed in the central area during the first dozen years, the PLAND of which was less than $0.5 \%$. In comparison to the PLAND change in natural tourism landscapes in each sub-area (Figure 8), the PLAND of human induced tourism landscapes 
increased but could be ignored because of its relatively small value. Therefore, only the eastern area continued as a tourism-oriented landscape evolution destination, while all other sub-areas and the area overall converted from degradation to growth during the two research periods.

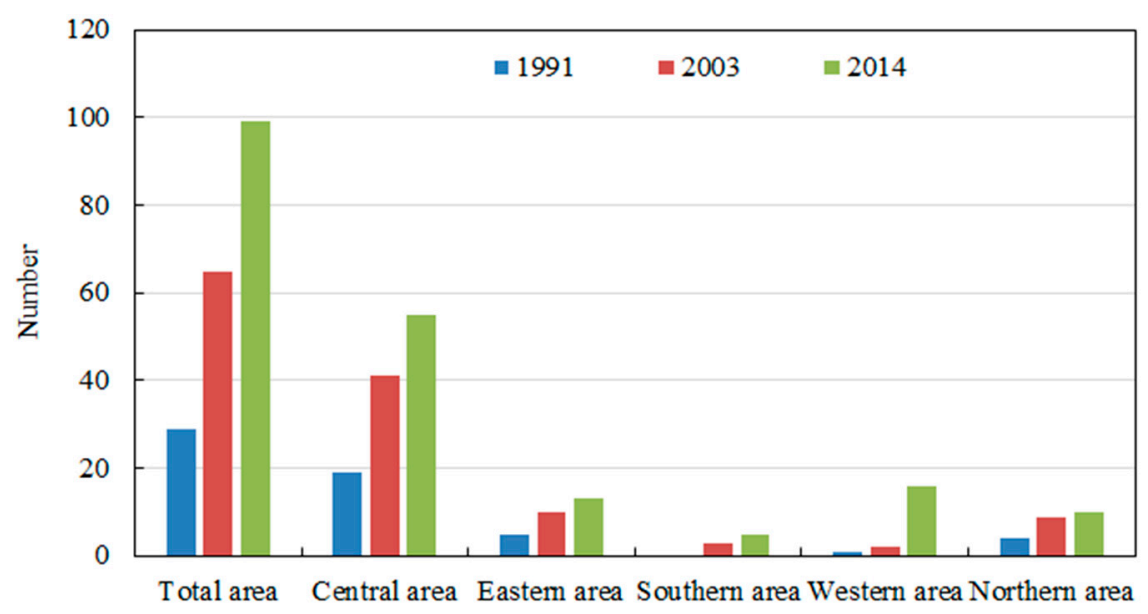

Figure 7. Number of human induced tourism landscapes in each area.

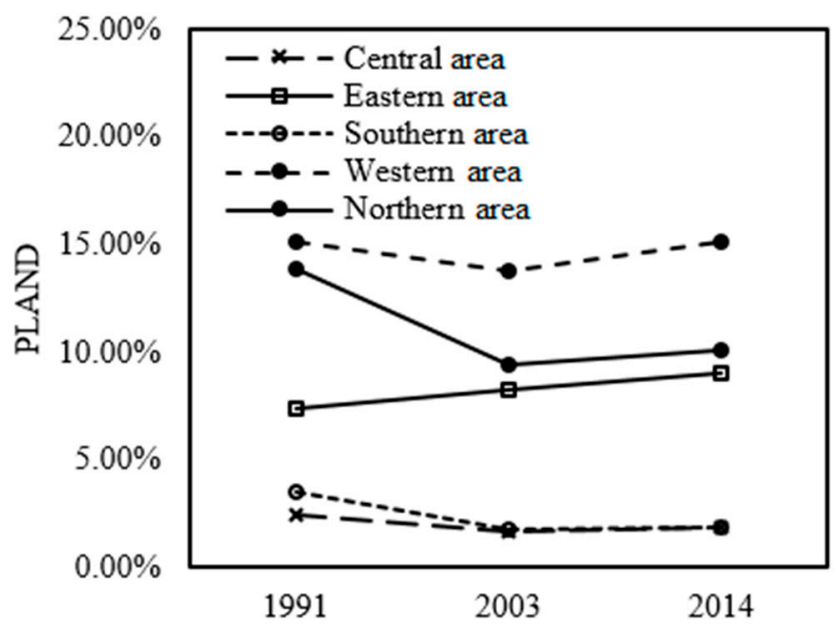

Figure 8. PLAND change of natural tourism landscapes in sub-areas.

Overall, it was evident from the landscape configuration and composition analysis that under significant urbanization, the original heterogeneous landscapes were gradual instead by homogeneous construction landscape. The ecological process among landscapes would be influenced due to the decreased connectivity, increased fragmentation, and decreased diversity. This creates an urgent need for spatial optimization to achieve healthy ecological landscape networks, and evolutionary sustainability for the entire area and its sub-areas.

\subsection{Spatial Optimization of Greenway Network}

\subsubsection{Landscape Ecological Service Value}

The spatial distribution of landscape ecological service value is the basis to identify the distribution of eco-function intensity, as this serves in the cost-distance analysis. First, the ecosystem services value was calculated from each valuable landscape type in 2014, based on the ecological value estimation of the Chinese domestic ecosystem service function [83]. Water landscapes had the highest proportion of 
ecosystem services value at $92 \%$, followed by park and green landscapes $(6.21 \%)$, forest $(1.5 \%)$, arable land $(0.21 \%)$, and tidal land $(0.08 \%)$ (see Table 3$)$.

Table 3. Landscape ecosystem services value in the study area.

\begin{tabular}{ccccc}
\hline Landscape Type & Landscape Area (ha) & $\begin{array}{c}\text { Unit Value of } \\
\text { Ecosystem Service } \\
\text { (USD/ha) }\end{array}$ & $\begin{array}{c}\text { Total Ecosystem } \\
\text { Service Value } \\
\text { (Million USD) }\end{array}$ & Value Proportion (\%) \\
\hline Water & 6902.61 & 11,067 & 7639.12 & 92 \\
Green and Park & 5691.21 & 906 & 515.62 & 6.21 \\
Forest & 691.10 & 1806 & 124.81 & 1.5 \\
Arable land & 628.64 & 276 & 17.35 & 0.21 \\
Tidal land & 19.98 & 3187 & 6.37 & 0.08 \\
Total & $13,933.54$ & - & 8303.27 & 100 \\
\hline
\end{tabular}

Note: 1 USD = 6.1428 CNY (Average annual exchange rate in 2014) [84].

Further, the spatial distribution of the ecological services value of different landscape types is illustrated in Figure 9a. The Yangtze River, Xuanwu Lake and Zhongshan Scenic Area comprise the main spatial distribution of the landscape that dominates the ecological service function. As the mother river of Nanjing, the Qinhuai River forms a loop across the middle and southern parts, and connects the Yangtze River with the city moat from the northeast to the southwest. These form the main river corridors and serve as the main transmission function to link sources with sinks.

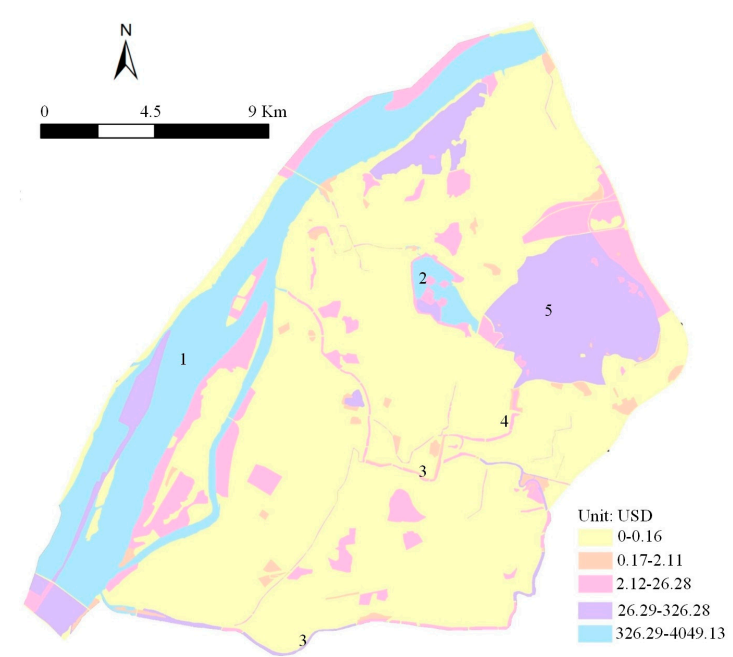

(a)

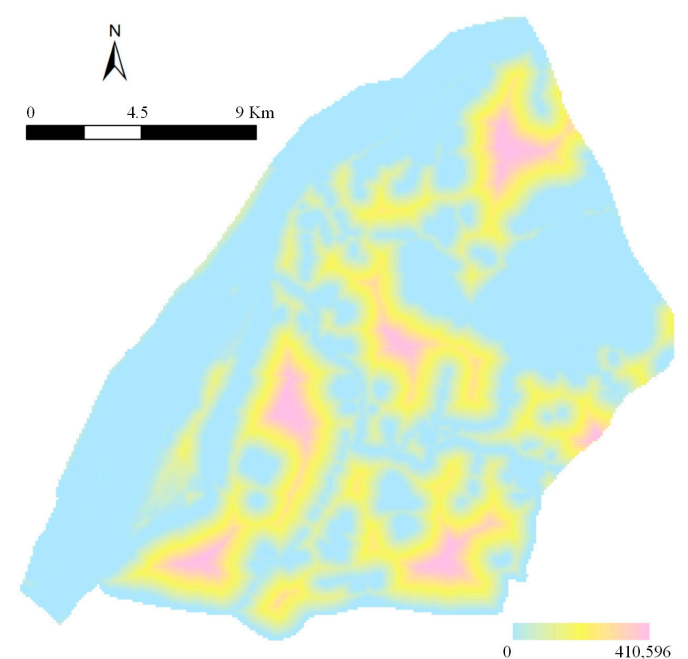

(b)

Figure 9. Landscape spatial distribution. (a) Ecosystem services value; (b) Accumulative cost distance (Notes: 1. Yangtze River; 2. Xuanwu Lake; 3. Qinhuai River; 4. City Moat; 5. Zhongshan Scenic Area).

\subsubsection{Identifying Sources}

Based on a comprehensive consideration of the research scale, landscape pattern continuity, and total value of ecosystem services of patches, repeated designs and presentations in ArcGIS were conducted. Further, the core patches of water, green and park, and forest lands with high ecosystem services value and areas greater than 40 ha were chosen as ecological sources [52,80]. Numerous sources were found, as shown in Figure 10. Zhongshan Scenic Area and Yangtze River Scenic Spot were the two largest ecological sources, and many other sources also spread widely, which provides the important foundation to promote healthy ecological process. However, from the perspective of spatial distribution, the sources had isolated distribution and weak interaction. In view of this, greenways should be further constructed. Moreover, considering connectivity, a buffer zone was created with the optimum threshold range of 50 to $100 \mathrm{~m}$ based on the distance threshold tests from 30 (image's 
minimum pixel unit) to $400 \mathrm{~m}$, with a distance interval of $10 \mathrm{~m}$. The goal was to consolidate and strengthen the ecological barrier function of the source.

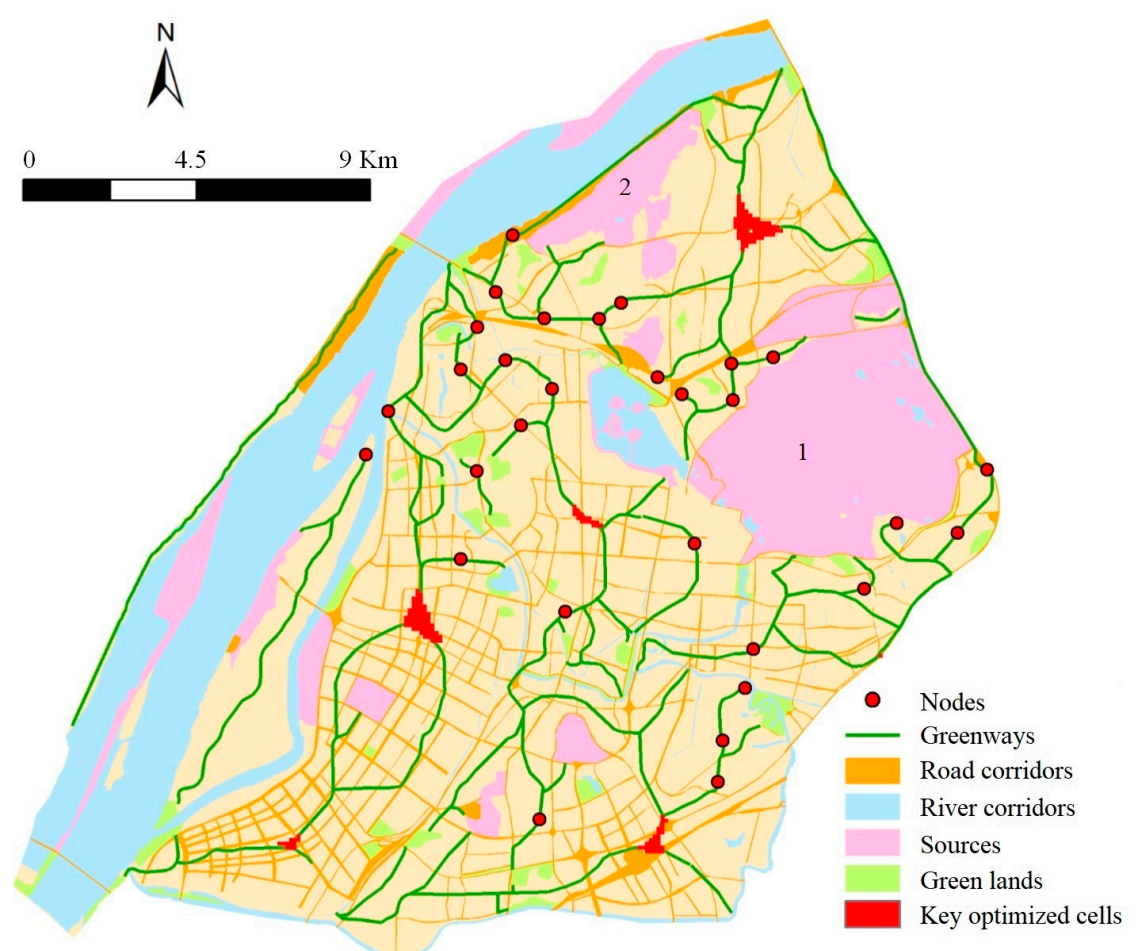

Figure 10. Greenway network construction. (Notes: 1. Zhongshan Scenic Area; 2. Yangtze River Scenic Spot).

\subsubsection{Constructing Greenways}

Taking both the landscape source and ecological resistance (i.e., the reciprocal of the proportion of ecosystem services value) into consideration [79], the COST DISTANCE module was utilized as an analysis tool in GIS to obtain the accumulative cost-distance surface of the landscape ecological function, from which the spatial distribution with a high value of cumulative cost distance corresponded to the urbanized construction location, and it was close to the sources (Figure 9b).

The main greenways can be set up among the green lands (i.e., those that were not chosen as sources), and the core patches, thus the connection and protection function among landscape components can be enhanced [52,80]. Bare land exerted the maximum resistance. Based on the cost-distance surface combined with the landscape features, the minimum cost path of the landscape flow was extracted to obtain potential locations for greenways (Figure 10). In addition, to reduce the negative effect of the sources cut by traffic lines and water ecosystems affected by built-up areas, as well as enhance the ecological function of urban corridors, more vegetation restoration should be strengthened on both sides of the corridors of roads and rivers.

\subsubsection{Establishing Nodes}

Ecological nodes are the key points that connect adjacent sources, and play an important role in landscape flow. They are especially important in a greenway network's connectivity, and generally located along each greenway segment. Based on the landscape pattern feature and the accumulative cost distance surface in the research area, ArcGIS was used to set thresholds repeatedly by analyzing the intersections and discontinuities between the minimum and maximum cost paths in the landscape flow. Finally, the spatial distribution of landscape ecological nodes was obtained. As shown in Figure 10, 
a total of 30 nodes were established that connect the greenways among sources closely to form a complete greenway network.

In addition, to conduct a spatial neighborhood analysis, the grid cells with the maximum and minimum values were extracted using the cells of the landscape cost-distance surface. Combined with the severe fragmentation characteristics of the important sources, the appropriate threshold was set, and identified the landscape cells with mutual restriction in the landscape function space. The key landscape cells that needed to be optimized were then confirmed (Figure 10). The landscape types must be adjusted or changed in these cases to avoid the landscape elements with a high value of ecological services that are adjacent directly to urban built spaces.

\subsection{Further Optimization for Evolutionary Sustainability}

Based on the evolution analysis, it can be inferred that the destination evolution was in a degenerate state, but demonstrated growth in the second period attributable to landscape conversion to reflect restoration in two stages. This included the entire area and its four sub-areas, except in the eastern area which showed perpetual growth characteristics. With respect to the sustainability of tourism destination evolution over time, three major propositions for potential transformations for the entire area as well as its sub-areas were formulated, based on the current tourism landscape spatial distribution.

Proposition 1. Natural tourism landscapes should be increased as much as possible.

As mentioned, natural landscapes have the highest value of ecosystem services, and assist to construct the greenways and green spaces as well, which are beneficial for both ecological and evolutionary sustainability of the destination. In particular, more attention is needed to increase the tidal lands that were neglected during the research period, so as to enhance the landscape diversity. In addition, because of their lower PLAND, increase in natural landscapes in the central and southern areas is needed to improve the landscape diversity, richness and function.

Proposition 2. Human induced tourism landscapes should be protected and developed effectively.

In urbanized areas, the demands for built-up land and transportation routes will increase in the context of further development. In this case, the current human landscapes with historical value should be protected or reconstructed. Further, plans to develop additional human landscapes with local characteristics, such as landmark buildings and distinctive roads would also improve the quantity and quality of tourism landscapes.

Proposition 3. No additional human induced tourism landscapes should be developed in the central area.

The central area is the local business district with the largest population density (33,400 people $/ \mathrm{km}^{2}$ [85]) in Nanjing, as well as has the highest density of human induced landscapes. These factors have caused the area to experience carrying capacity pressures on the ecological environment, such as severe traffic congestion, large amount of garbage, low air quality, etc. In view of this, it is of necessity to control the additional construction of hotels and shopping places, which could reduce impacts from lodging accommodations and retail shopping.

\section{Discussion}

Spatiotemporal changes in global and regional environments and their effects attributable to human activities have become major issues. The development of urban tourism destinations is a process of natural landscape transformation for both the urban development and tourism sectors. Thus, in this context, there is a major need to integrate ideas and methods to mitigate the problems encountered in the development of urban tourism destinations. Moreover, from the aspect of ecological 
dimension, sustainable tourism is concerned with ensuring development that is compatible with maintenance of essential ecological processes [86]. However, ecological process of landscapes along with their ecosystem services value is always a factor that is less considered in traditional urban or tourism destination planning. This is especially the case in China that leads to dubious sustainable practices $[44,46]$.

In urban tourism destinations, ecosystem functions that translate to services in natural tourism landscapes are related to tidal land, forests, park and green land, or water bodies, etc. However, human induced tourism landscapes and other urban landscapes are developed highly and likely affect ecological linkages. The abundance of natural tourism landscapes and the spatial distribution of human induced tourism landscapes have a direct effect on urban ecology and tourism development. Hence, this issue needs to be assessed further and integrated in tourism industrial development plans, infrastructure projects, and regional planning.

Based on a highly urbanized tourism destination (core area of Nanjing, China), this study integrated RS, GIS, and spatial metrics to analyze at the scales of particular area and sub-areas in the patterns and distribution of changes in urban and tourism landscapes for the past 20 years. The integrated approach aims to provide solutions to regional planners whereby real landscape changes have been attributed to the drastic expansion of urban tourism and urbanization. The quantitative approaches as such are relatively rare in both urban planning and tourism development, as they usually tend to address some specific problems, e.g., particular species conservation [81,87], or the community-based tourism development [24,25], etc. Moreover, Zhang and Wang [71] stated that landscape metrics can facilitate the construction of ecological networks of greenways. It has been widely applied in landscape planning projects as it provides the basic quantitative information of landscape composition and configuration $[9,86]$.

Using the least-cost modeling, which is a superior tool because it yields explicit results and allows for parameterization and testing in empirical studies [79], a landscape dynamics and evolution analysis was further conducted to construct a greenway network by optimizing the elements and cells. In addition, the study proposed further optimization strategies based on the conceptual evolution model. The optimization results were based on the perspectives of urban ecology and tourism destination evolution, respectively, but were complementary and constituted a unit for landscape planning. Moreover, the integrated approach from the use of such technologies and methods is objective and replicable. Largely, this involves a stepwise process that can be replicated in other tourism destinations to provide a more practical management framework.

In this case study, three conclusions were derived. First, landscapes have experienced drastic changes because of urbanization and tourism. Fundamentally, a homogeneous urban construction landscape has replaced the original heterogeneous and diversified landscapes, especially arable and tidal lands. The landscape patterns tended toward simplification and disequilibrium. Simultaneously, given the increased fragmentation and decreased connectivity, it is clear that rapid urbanization has neglected the landscape ecological process. Fischer and Lindernmayer [88] argue that landscape heterogeneity is of great importance, and deserve attention in human-modified landscapes. Likewise, Gurrutxaga et al. [74] also state the necessary management of agricultural and forestry holdings in the ecological network. Both studies along with this research demonstrate diverse landscapes will be beneficial for a healthy ecosystem. In modern China, there has been extreme attention towards urban infrastructure development, much to the loss of ecological value of arable or tidal land, which poses difficulties to support the sustainability of an urban ecosystem.

Second, an entire greenway network was constructed that identified sources, greenways, and nodes to reduce fragmentation and strengthen connectivity among the landscape elements. In addition, five key landscape cells were extracted to reduce the barriers of urban agglomeration to landscape function. This process and outcomes was in concert with Opdam et al. [89] as they noted that ecological networks are essential to achieve ecological sustainability, which are constructed by the linkage among core areas, corridors, nodes and buffer zones [74]. 
Third, from the evolutionary perspective, it is highly important to enhance the natural tourism landscapes in all sub-areas, especially the central and southern areas. This would promote the evolutionary sustainability for a destination with tourism growth at different scales, and is helpful for the construction of greenway network as well. Moreover, human induced tourism landscapes should also be protected carefully and developed effectively in the study area. It is of noted importance for the central area to transfer tourism service functions that includes lodging accommodations and retail shopping to other areas due to their negative ecological effects.

Although this research explored the sustainability of an urban tourism destination through the combination of urban ecology and tourism, there are limitations that need to be addressed for future research. Restricted by the distribution characteristics of the study area and data acquisition, this study chose the landscape ecosystem services value as the main factor to identify the sources and establish the resistance surface. Hence, other factors should also be considered in future studies to make more accurate identification of sources and construction of greenway networks [73,80]. In addition, the types and width of greenways should be classified and designed more specifically. Moreover, a conceptual model based on landscape provides the effects of the landscape patterns as a tool to describe the evolution of a tourism destination, but more research is needed to prove its applicability to landscape planning. Further, more time span is required for future evolution research as the tourism destination evolution is a long process.

Finally, with the gradual formation of relations among urbanization, tourism, and ecology, additional attention on the part of researchers, planners, urban managers, and tourism-related departments has been given to understand and promote sustainable development. Given the dramatic growth in urbanization in China and other developing countries, it is imperative to focus on development and tourism sector development collectively because of the interactions among landscapes, urban expansion, and tourism. Similar to this study, constructions of landscape optimization system should receive more attention in the future. Urbanization and urban mass tourism will continue to be major economic drivers in China, both of which have strong influences on landscapes, and likely result in new environmental challenges.

Acknowledgments: This work was supported by the Jiangsu Overseas Research \& Training Program for University Prominent Young \& Middle-aged Teachers and Presidents in 2016, and the Shenzhen Science and Technology Innovation Committee, Science and Technology Project (Grant Number JCYJ20150831194835299). We also thank the anonymous reviewers for their valuable comments, which greatly improved the manuscript.

Author Contributions: Lingling Chen and Lin Yi designed the research; Lingling Chen collected data and analyzed the data; Brijesh Thapa, Jinwon Kim, and Lin Yi contributed to progress of research idea; Lingling Chen, Brijesh Thapa, and Jinwon Kim wrote the paper. All authors have read and approved the final manuscript.

Conflicts of Interest: The authors declare no conflict of interest.

\section{References}

1. Ashworth, G.; Page, S.J. Urban tourism research: Recent progress and current paradoxes. Tour. Manag. 2011, 32, 1-15. [CrossRef]

2. Miller, D.; Merrilees, B.; Coghlan, A. Sustainable urban tourism: Understanding and developing visitor pro-environmental behaviours. J. Sustain. Tour. 2015, 23, 26-46. [CrossRef]

3. Yeh, C.T.; Huang, S.L. Investigating spatiotemporal pattern of landscape diversity in response to urbanization. Landsc. Urban Plan. 2009, 93, 151-162. [CrossRef]

4. Yu, X.J.; Ng, C.N. Spatial and temporal dynamics of urban sprawl along two urban-rural transects: A case study of Guangzhou, China. Landsc. Urban Plan. 2007, 79, 96-109. [CrossRef]

5. Su, S.L.; Xiao, R.; Jiang, Z.L.; Zhang, Y. Characterizing landscape pattern and ecosystem service value changes for urbanization impacts at an eco-regional scale. Appl. Geogr. 2012, 34, 295-305. [CrossRef]

6. De Groot, R.S.; Alkemade, R.; Braat, L.; Hein, L.; Willemen, L. Challenges in integrating the concept of ecosystem services and values in landscape planning, management and decision making. Ecol. Complex. 2010, 7, 260-272. [CrossRef] 
7. Deng, J.S.; Wang, K.; Hong, Y.; Qi, J.G. Spatio-temporal dynamics and evolution of land use change and landscape pattern in response to rapid urbanization. Landsc. Urban Plan. 2009, 92, 187-198. [CrossRef]

8. Solon, J. Spatial context of urbanization: Landscape pattern and changes between 1950 and 1990 in the Warsaw metropolitan area, Poland. Landsc. Urban Plan. 2009, 93, 250-261. [CrossRef]

9. Fang, C.L.; Li, G.D.; Wang, S.J. Changing and differentiated urban landscape in China: Spatiotemporal patterns and driving forces. Environ. Sci. Technol. 2016, 50, 2217-2227. [CrossRef] [PubMed]

10. Soto, M.T.R.; Clavé, S.A. Second homes and urban landscape patterns in Mediterranean coastal tourism destinations. Land Use Policy 2017, 68, 117-132. [CrossRef]

11. Ma, M.; Hassink, R. Path dependence and tourism area development: The case of Guilin, China. Tour. Geogr. 2014, 16, 580-597. [CrossRef]

12. Enright, M.J.; Newton, J. Tourism destination competitiveness: A quantitative approach. Tour. Manag. 2004, 25, 777-788. [CrossRef]

13. Eshliki, S.A.; Kaboudi, M. Community perception of tourism impacts and their participation in tourism planning: A case study of Ramsar, Iran. Procedia Soc. Behav. Sci. 2012, 36, 333-341. [CrossRef]

14. Ólafsdóttir, R.; Runnström, M.C. A GIS approach to evaluating ecological sensitivity for tourism development in fragile environments. A case study from SE Iceland. Scand. J. Hosp. Tour. 2009, 9, 22-38. [CrossRef]

15. Yianna, F.; Poulicos, P. GIS Contribution for the Evaluation and Planning of Tourism: A Sustainable Tourism Perspective. Available online: http:/ / www.iacm.forth.gr/papers/HellasGI-Thess.pdf (accessed on 11 June 2017).

16. Su, S.; Jiang, Z.; Zhang, Y. Transformation of agricultural landscapes under rapid urbanization: A threat to sustainability in Hang-Jia-Hu region, China. Appl. Geogr. 2011, 31, 439-449. [CrossRef]

17. Lausch, A.; Herzog, F. Applicability of landscape metrics for the monitoring of landscape change: Issues of scale, resolution and interpretability. Ecol. Indic. 2002, 2, 3-15. [CrossRef]

18. Herold, M.; Couclelis, H.; Clarke, K.C. The role of spatial metrics in the analysis and modeling of urban land use change. Comput. Environ. Urban Syst. 2005, 29, 369-399. [CrossRef]

19. Reis, J.P.; Silva, E.A.; Pinho, P. Spatial metrics to study urban patterns in growing and shrinking cities. Urban Geogr. 2016, 37, 246-271. [CrossRef]

20. Evans, G. Planning for urban tourism: A critique of borough development plans and tourism policy in London. Int. J. Tour. Res. 2000, 2, 307-326. [CrossRef]

21. Costa, C. An emerging tourism planning paradigm? A comparative analysis between town and tourism planning. Int. J. Tour. Res. 2001, 3, 425-441. [CrossRef]

22. Li, M.M.; Fang, L.; Huang, X.T.; Goh, C. A spatial-temporal analysis of hotels in urban tourism destination. Int. J. Hosp. Manag. 2015, 45, 34-43. [CrossRef]

23. Freestone, R. Urban Planning in a Changing World: The Twentieth Century Experience, 1st ed.; Routledge: Abingdon, UK, 2000; ISBN 978-0-419-24650-3.

24. Nunkoo, R.; Ramkissoon, H. Small island urban tourism: A residents' perspective. Curr. Issues Tour. 2010, 13, 37-60. [CrossRef]

25. Nunkoo, R.; Ramkissoon, H. Residents' satisfaction with community attributes and support for tourism. J. Hosp. Tour. Res. 2011, 35, 171-190. [CrossRef]

26. Harrill, R. Residents' attitudes toward tourism development: A literature review with implications for tourism planning. J. Plan. Lit. 2004, 18, 251-266. [CrossRef]

27. Gu, H.M.; Ryan, C. Tourism destination evolution: A comparative, study of Shi Cha Hai Beijing Hutong businesses' and residents' attitudes. J. Sustain. Tour. 2012, 20, 23-40. [CrossRef]

28. Ludntorp, S.; Wanhill, S. The resort lifecycle theory generating processes and estimation. Ann. Tour. Res. 2001, 28, 947-964. [CrossRef]

29. Pavlovich, K. A rhizomic approach to tourism destination evolution and transformation. Tour. Manag. 2014, 41,1-8. [CrossRef]

30. Pietsch, M. GIS in landscape planning. In Landscape Planning; Ozyavuz, M., Ed.; InTech: Vienna, Austria, 2012; pp. 55-84. Available online: http:/ / www.intechopen.com/books/landscape-planning/gis-in-landscapeplanning (accessed on 17 December 2017).

31. JovanoviĆ, V.; Njeguš, A. The application of GIS and its components in tourism. Yugosl. J. Oper. Res. 2008, 18, 261-272. [CrossRef]

32. Boers, B.; Cottrell, S. Sustainable tourism infrastructure planning: A GIS-supported approach. Tour. Geogr. 2007, 9, 1-21. [CrossRef] 
33. Brown, G. Mapping landscape valued and development preferences: A method for tourism and residential development planning. Int. J. Tour. Res. 2006, 8, 101-113. [CrossRef]

34. Gaughan, A.E.; Binford, M.W.; Southworth, J. Tourism, forest conversion, and land transformations in the Angkor basin, Cambodia. Appl. Geogr. 2009, 29, 212-223. [CrossRef]

35. Kang, S.; Kim, J.; Nicholls, S. National tourism policy and spatial patterns of domestic tourism in South Korea. J. Travel Res. 2014, 53, 791-804. [CrossRef]

36. Lau, G.; McKercher, B. Understanding tourist movement patterns in a destination: A GIS approach. Tour. Hosp. Res. 2006, 7, 39-49. [CrossRef]

37. Shoval, N.; McKercher, B.; Ng, E.; Birenboim, A. Hotel location and tourist activity in cities. Ann. Tour. Res. 2011, 38, 1594-1612. [CrossRef]

38. Kim, J.; Nicholls, S. Influence of the measurement of distance on assessment of recreation access. Leis. Sci. 2016, 38, 118-139. [CrossRef]

39. Kim, J.; Nicholls, S. Using geographically weighted regression to explore the equity of public open space distributions. J. Leis. Res. 2016, 48, 105-133. [CrossRef]

40. Loures, L.; Loures, A.; Nunes, J.; Panagopoulos, T. Landscape valuation of environmental amenities throughout the application of direct and indirect methods. Sustainability 2015, 7, 794-810. [CrossRef]

41. Brown, G.; Weber, D. Public Participation GIS: A new method for national park planning. Landsc. Urban Plan. 2011, 102, 1-15. [CrossRef]

42. Bunruamkaew, K.; Murayama, Y. Land use and natural resources planning for sustainable ecotourism using GIS in Surat Thani, Thailand. Sustainability 2012, 4, 412-429. [CrossRef]

43. Yang, B.; Madden, M.; Kim, J.; Jordan, T. Geospatial analysis of barrier island beach availability to tourists. Tour. Manag. 2012, 33, 840-854. [CrossRef]

44. Zhou, L.Q.; Zhang, W.M. A review on central issues in tourism planning by academics in China since 2000. J. Zhejiang Univ. 2010, 40, 134-143. (In Chinese)

45. Wu, J.G. Urban ecology and sustainability: The state-of-the-science and future directions. Landsc. Urban Plan. 2014, 125, 209-221. [CrossRef]

46. Zhou, K.H.; Liu, Y.L.; Tan, R.H.; Song, Y. Urban dynamics, landscape ecological security, and policy implication: A case study from the Wuhan area of central China. Cities 2014, 41, 141-153. [CrossRef]

47. Cadenasso, M.L.; Pickett, S.T.A. Urban principles for ecological landscape design and management: Scientific fundamentals. Cities Environ. 2008, 1, 1-16. [CrossRef]

48. Baggethun, E.G.; Barton, D.N. Classifying and valuing ecosystem services for urban planning. Ecol. Econ. 2013, 86, 235-245. [CrossRef]

49. Jim, C.Y.; Chen, W.Y. Ecosystem services and valuation or urban forests in China. Cities 2009, 26, 187-194. [CrossRef]

50. Chen, L.D.; Fu, B.J.; Zhao, W.W. Source-sink landscape theory and its ecological significance. Front. Biol. China 2008, 3, 131-136. [CrossRef]

51. Haase, C.G.; Fletcher, R.J., Jr.; Slone, D.H.; Reid, J.P.; Bulter, S.M. Landscape complementation revealed through bipartite networks: An example with the Florida manatee. Landsc. Ecol. 2017, 32, 1999-2014. [CrossRef]

52. Yue, D.P.; Wang, J.P.; Liu, Y.B.; Li, H.L.; Xie, H.C.; Wang, D.M. Landscape pattern optimization based on RS and GIS in Northwest of Beijing. Acta Geogr. Sin. 2007, 62, 1223-1231. (In Chinese)

53. Ahern, J. Greenways as planning strategy. Landsc. Urban Plan. 1995, 33, 131-155. [CrossRef]

54. Fabos, J.G.; Ryan, R.L. An introduction to greenway planning around the world. Landsc. Urban Plan. 2006, 76, 1-6. [CrossRef]

55. Ahern, J. Urban landscape sustainability and resilience: The promise and challenges of integrating ecology with urban planning and design. Landsc. Ecol. 2013, 28, 1203-1212. [CrossRef]

56. Pino, J.; Marull, J. Ecological networks: Are they enough for connectivity conservation? A case study in the Barcelona Metropolitan Region (NE Spain). Land Use Policy 2012, 29, 684-690. [CrossRef]

57. Jacobsen, J.K.S. Use of landscape perception methods in tourism studies: A review of photo-based research approaches. Tour. Geogr. 2007, 9, 234-253. [CrossRef]

58. Forman, R.T.T. Chapter 1: Foundations. In Urban Ecology: Science of Cities; Cambridge University Press: Cambridge, UK, 2014. 
59. Yu, J.G.; Wang, L.H. Landscape structure analyses for urban tourism planning: A case study of Dalian. J. Nat. Resour. 2007, 22, 281-289. (In Chinese)

60. Chen, X.Q.; Wu, J.G. Sustainable landscape architecture: Implications of the Chinese philosophy of "unity of man with nature" and beyond. Landsc. Ecol. 2009, 24, 1015-1026. [CrossRef]

61. Zhang, H.H.; Zeng, Y.N.; Jin, X.B.; Shu, B.R.; Zhou, Y.K.; Yang, X.H. Simulating multi-objective land use optimization allocation using Multi-agent system-A case study in Changsha, China. Ecol. Model. 2016, 320, 334-347. [CrossRef]

62. Liu, Y.L.; Tang, W.; He, J.H.; Liu, Y.F.; Ai, T.H.; Liu, D.F. A land-use spatial optimization model based on genetic optimization and game theory. Comput. Environ. Urban Syst. 2015, 49, 1-14. [CrossRef]

63. Wang, S.D.; Wang, X.C.; Zhang, H.B. Simulation on optimized allocation of land resource based on DE-CA model. Ecol. Model. 2015, 314, 135-144. [CrossRef]

64. Wang, X.X. Urbanization Rate of Nanjing in Jiangsu Has Reached 81\%. Available online: http://www. ciudsrc.cn/new_chengshihualv/gedi/2016-11-30/108603.html (accessed on 24 October 2017). (In Chinese)

65. Jessen, L.I.F.; Frans, J.M.; Wel, V.D. Accuracy assessment of satellite derived land-cover data: A review. Photogramm. Eng. Remote Sens. 1994, 60, 410-432.

66. Kromroy, K.; Ward, K.; Castillo, P.; Juzwik, J. Relationships between urbanization and the oak resource of the Minneapolis/St. Paul Metropolitan area from 1991 to 1998. Landsc. Urban Plan. 2007, 80, 375-385. [CrossRef]

67. Leitão, A.B.; Ahern, J. Applying landscape ecological concepts and metrics in sustainable landscape planning. Landsc. Urban Plan. 2002, 59, 65-93. [CrossRef]

68. Zhu, Q.; Yu, K.J.; Li, D.H. The width of ecological corridor in landscape planning. Acta Ecol. Sin. 2005, 25, 2406-2412. (In Chinese)

69. Ignatieva, M.; Stewart, G.H.; Meurk, C. Planning and design of ecological networks in urban areas. Landsc. Ecol. Eng. 2011, 7, 17-25. [CrossRef]

70. Tan, K.W. A greenway network for Singapore. Landsc. Urban Plan. 2006, 76, 45-66. [CrossRef]

71. Zhang, L.Q.; Wang, H.Z. Planning an ecological network of Xiamen island (China) using landscape metrics and network analysis. Landsc. Urban Plan. 2006, 78, 449-456. [CrossRef]

72. Zhou, N.X.; Yu, K.J.; Huang, Z.F. Perspectives on greenway development. Acta Ecol. Sin. 2006, 26, 3108-3116. (In Chinese)

73. Teng, M.J.; Wu, C.G.; Zhou, Z.X.; Lord, E.; Zheng, Z.M. Multipurpose greenway planning for changing cities: A framework integrating priorities and a least-cost path model. Landsc. Urban Plan. 2011, 103, 1-14. [CrossRef]

74. Gurrutxaga, M.; Lozano, P.J.; del Barrio, G. GIS-based approach for incorporating the connectivity of ecological networks into regional planning. J. Nat. Conserv. 2010, 18, 318-326. [CrossRef]

75. Theobald, D.M. Exploring the functional connectivity of landscapes using landscape networks. In Connectivity Conservation; Crooks, K.R., Sanjayan, M., Eds.; Cambridge University Press: Cambridge, UK, 2006; pp. 416-443.

76. Adriaensen, F.; Chardon, J.P.; De Blust, G.; Swinnen, E.; Villalba, S.; Gulinck, H.; Matthysen, E. The application of 'least-cost' modelling as a functional landscape model. Landsc. Urban Plan. 2003, 64, 233-247. [CrossRef]

77. Su, Y.X.; Chen, X.Z.; Liao, J.S.; Zhang, H.O.; Wang, C.J.; Ye, Y.Y.; Wang, Y. Modeling the optimal ecological security pattern for guiding the urban constructed land expansions. Urban For. Urban Green. 2016, 19, 35-46. [CrossRef]

78. Li, Y.; Sun, X.; Zhu, X.; Cao, H. An early warning method of landscape ecological security in rapid urbanizing coastal areas and its application in Xiamen, China. Ecol. Model. 2010, 221, 2251-2260. [CrossRef]

79. Richard, Y.; Armstrong, D.P. Cost distance modelling of landscape connectivity and gap-crossing ability using radio-tracking data. J. Appl. Ecol. 2010, 47, 603-610. [CrossRef]

80. Wu, J.S.; Yue, X.X.; Qin, W. The establishment of ecological security patterns based on the redistribution of ecosystem service value: A case study in the Liangjiang New Area, Chongqing. Geogr. Res. 2017, 36, 429-440. (In Chinese)

81. Zhu, L.; Zhan, X.; Meng, T.; Zhang, S.N.; Wei, F.W. Landscape features influence gene flow as measured by cost-distance and genetic analyses: A case study for giant pandas in the Daxiangling and Xiaoxiangling Mountains. BMC Genet. 2010, 11, 72. [CrossRef] [PubMed]

82. Yang, J.; Ge, Y.T.; Xi, J.C.; Ge, Q.S.; Li, X.M. Spatial-temporal island tourismification effects differentiation of Changhai county. Acta Geogr. Sin. 2016, 71, 1075-1087. (In Chinese) 
83. Chen, Z.X.; Zhang, X.S. Value of China's ecological system. Chin. Sci. Bull. 2000, 45, 870-876. [CrossRef]

84. State Administration of Foreign Exchange. Annual Report of the State Administration of Foreign Exchange (2014). Available online: http:/ / www.safe.gov.cn/wps/wcm/connect/safe_web_store/safe_web/ cbw/whglnb/node_cbw_glwg_store/5643fa80485537f095acf7de2bce1a15 (accessed on 15 November 2017). (In Chinese)

85. Fenghua, X. Densely Populated in the Central Area of Nanjing. Available online: http://news.sohu.com/ 20120425/n341540944.shtml (accessed on 20 November 2017). (In Chinese)

86. Timur, S.; Getz, D. Sustainable tourism development: How do destination stakeholders perceive sustainable urban tourism? Sustain. Dev. 2009, 17, 220-232. [CrossRef]

87. Damschen, E.J.; Haddad, N.M.; Orrock, J.L.; Tewksbury, J.J.; Levey, D.J. Corridors increase plant species richness at large scales. Science 2006, 313, 1284-1286. [CrossRef] [PubMed]

88. Fischer, J.; Lindenmayer, D.B. Landscape modification and habitat fragmentation: A synthesis. Glob. Ecol. Biogeogr. 2007, 216, 265-280. [CrossRef]

89. Opdam, P.; Steingröver, E.; van Rooij, S. Ecological networks: A spatial concept for multi-actor planning of sustainable landscapes. Landsc. Urban Plan. 2006, 75, 322-332. [CrossRef]

(C) 2017 by the authors. Licensee MDPI, Basel, Switzerland. This article is an open access article distributed under the terms and conditions of the Creative Commons Attribution (CC BY) license (http:/ / creativecommons.org/licenses/by/4.0/). 